\title{
The occurrence of priority substances in surface water
}

\author{
Katarzyna Moraczewska-Majkut ${ }^{1, *}$, and Katarzyna Kalemba ${ }^{2}$ \\ ${ }^{1}$ The Silesian University of Technology, Faculty of Energy and Environmental Engineering, Institute of Water and Wastewater \\ Engineering, Konarskiego 18, 44-100, Gliwice, Poland \\ 2 The Silesian University of Technology, Faculty of Energy and Environmental Engineering, Institute of Water and Wastewater \\ Engineering, Konarskiego 18, 44-100, Gliwice, Poland
}

\begin{abstract}
In the article the presence of substances, specified in the Water Framework Directive as a priority, in the aquatic environment was analyzed. The impact of priority substances on organisms especially on human health and ways of reducing their occurrence was discussed. Particular attention was paid to the legal aspects of the presence of these compounds in the aquatic environment and the principles of monitoring of priority substances.
\end{abstract}

\section{Introduction}

The substances known as toxic are compounds that cause life-threatening organisms or their death. Toxic contaminations have a major impact on the quality of surface water. Concentrations of substances in excess of environmental quality standards can cause poisoning and death of aquatic organisms. The awareness of this threat has led to the emergence of legislation in the European Union that aims to protect the environment and, in particular, protect water from chemical pollution. Mainly, in the aquatic environment pollutants migrate between particular elements of the environment [1].

In Directive 2000/60/EC of the European Parliament and of the Council of 23 October 2000 establishing a framework for Community action in the field of water policy known as the Water Framework Directive, 33 priority substances were identified, 13 of which were identified as priority hazardous substances. These concepts are defined in the above directive: "Prioritized substances are substances that pose a particular threat to the aquatic environment," while "priority substances are substances or groups of substances that pose significant environmental risks due to their persistence, toxicity, bioaccumulation, low susceptibility to degradation and risk to human health "[1]. Currently, 45 substances are in the list of priority substances in the field of water policy [2].

\section{Analysis of the presence of priority substances in surface waters}

The world wide pollution of freshwater ecosystems with thousands of industrial chemicals is increasing, which is crucial problem of modern environmental protection. More than a third of the available fresh water on Earth is used for agricultural, industrial and domestic purposes and all these activities lead to the contamination of waters with numerous synthetic compounds. Every year, many hazardous chemicals use in industrial and consumer products can in part get into natural waters. Additional, pollution come from diffuse sources, including from agriculture, where millions of tons of pesticides are used each year [3].

Understanding the causes and sources of water pollution by priority substances allows Member States of the European Union to better control these pollutants. The main sources of pollutants in these waters are atmospheric deposition, surface runoff, sewage discharges and leachate from landfills [4]. Pollution present in the atmosphere can settle on the entire surface of the catchment and can be washed away by atmospheric precipitation, becoming part of surface runoff of rainwater. Pollutants can also penetrate directly from atmospheres into water bodies, rivers or coastal waters. Substances can be present in the atmosphere either as gaseous particles, solid particles or liquid. All these compounds settle on the surface of the Earth through wet or dry deposits [5].

Urban pollution has a significant impact on the quality of all ecosystems. In particular, changes in the use of land in urban planning areas significantly change the condition of the water environment, inhibit the seeping of rainwater into the ground and cause flooding. In addition, urbanization has a strong influence on the quality of rainwater, which is increasingly contaminated by biological and physicochemical substances of anthropogenic origin. Contaminated rainwater is one of the major sources of pollutants released into waters [6,7].

Studies have shown that waste water treatment plants are a significant source of water pollution by priority substances. The waste water come from industrial plants or urban areas contain pollutants such as polycyclic aromatic hydrocarbons, phthalates, phenols, phenols, flame retardants and others. The fact that waste water treatment plants are designed primarily to remove organic matter, nitrogen and phosphorus from sewage

Corresponding author: katarzyna.moraczewska-majkut@polsl.pl 
and there are no legal regulations on the concentration of priority substances in sewage causes many of these substances to pass from conventional treatment plants to surface water, causing them to contaminate $[8,9]$. Landfills are also a source of environmental pollution by priority substances. The big problem is that these compounds do not appear as separate fractions but as additives to stored products such as packaging, plastics, textiles or electronics. In addition, leachate effluents contain high concentrations of suspended and dissolved organic matter, which increases the potential for transport of these contaminants [10-13].

\section{Effect of priority substances on living organisms}

Priority substances are substances that are particularly harmful to the health and life of organisms. Presence in the waters of these substances and in particular concentrations above acceptable levels, can cause poisoning as well as extinction not only of aquatic organisms, but also of benefit or contact with human and animal water [14-17]. High toxicity, persistence, and the ability of priority substances to bioaccumulate are the most dangerous factors for health and life. Much of the low water-soluble priority substances are readily soluble in fatty tissues of living organisms. This causes the concentration of these toxins in human and animal organisms much higher than in the environment. This process, called bioaccumulation, means that organisms at the end of the food pyramid and above all people are exposed to the accumulation of toxic substances in their bodies [18-25]. Heavy metals, such as lead, cadmium and mercury in the priority substance group, interfere with the function of living organisms by destroying or impairing their cells. Cadmium causes permanent damage to the kidneys and the skeletal system, lung cancer and heart disease $[25,26]$. Mercury damages the nervous system [19]. Lead is responsible for anemia and for impairment of the function of the nervous system $[27,28]$. Scientific studies also prove that many of the substances in question cause cancer, disrupt the effects of the nervous and hormonal systems of humans and animals, cause foetus damage, mutations and damage to internal organs, especially liver [14-28].

\section{Surface water monitoring for the presence of priority substances}

Within the framework of the State Environmental Monitoring, the quality of surface waters is assessed, which results from the Water Law Act [29]. Its purpose is to provide a basis for action to improve water quality and protect against pollution from the agro-industrial, agricultural and industrial sectors - including protection against salinity and priority substances [30].

Water quality measurements are carried out at the measuring and control points of the rivers and in the transitional and coastal waters of the Baltic Sea, by the Voivodship Inspectorates for Environmental Protection
[30]. The assessment of the state of the water is based on the classification according to the Regulation of the Minister of the Environment of 21 July 2016 on the classification of the state of surface water bodies and environmental quality standards for priority substances [31]. The state of unitary bodies of surface water is classified on the basis of the results of the studies conducted for the presence of priority substances and other pollutants in these waters. The classification of the chemical state of the waters is based on at least 12 measurement results from the monitoring of priority substances comparing them to the environmental quality standards for each category of surface water (contained in Annex 9 of the Regulation). Classification of individual physico-chemical elements takes place annually [31].

According to the Water Law [29], the monitoring consists of studies on the tissues of living organisms of five priority substances: diclofen, perfluorooctanesulfonic acid and its derivatives (PFOS), dioxins and dioxin-like compounds, hexabromocyclo-dodecane (HBCDD) and heptachlor and heptachlor epoxide. It belongs to the Chief Inspectorate of Environmental Protection. From 2019 laboratory analyzes for seven of the "new" substances (quinoxyfen, aclonifen, bifenox, cyberatine, cypermethrin, dichlorophos and terbutryne) will be carried out by four provincial environmental inspectorates. In 2015, the Chief Inspector of Environmental Protection has appointed the Provincial Inspectorate for Environmental Protection for this purpose: in Lublin, Szczecin, Łódź and Bialystok.

\subsection{Ranking of priority substances based on water monitoring data}

Ranking of priority substances is based on data from the monitoring carried out by the Voivodship Inspectorates for Environmental Protection in order to identify those priority substances whose concentration exceeds the limits and then determine the validity of these pollutants. When compiling the ranking of priority substances, their ecological sustainability, toxicity, frequency of exceeds and environmental discharges are taken into account. Ranking is prepared in three stages. During the first stage, the frequency of exceeding the average annual values of water quality standards in relation to the number of determinations of a given pollutant at each control and measurement point of the water body is determined. Using these data, priority substances are ranked in descending order. The second step is to determine the frequency of the priority substance in relation to the number of measurements performed at all control points. The concentration of the substance is greater than the detection threshold but lower than the concentration limit. Just like before, the results are laid down in a descending order. In the third step, the rest of the substance that was not classified during the first or second stage is placed on the previously prepared ranking list of priority substances from the first and second stage [32]. 


\subsection{Ranking of priority substances based on emission data}

The ranking of priority substances can also be made according to the assessment of the priority substances released into the environment. Priority substances are ranked each year in descending order according to the total discharged volume in a given region [32]. Data on discharges can be found in the European Pollutant Release and Transfer Register (E-PRTR) [32]. Regulation (EC) No 166/2006 of the European Parliament and of the Council of 18 January 2006 on the establishment of a European Pollutant Release and Transfer Register and amending Council Directive 91/689/EEC and 96/61/EC established an integrated European Pollutant Release and Transfer Register Pollution (E-PRTR), which is commonly available in the electronic database [33]. Each EU Member State was obliged to establish a National Register and Transfer of Pollution (PRTR) [34]. Poland fulfills this requirement by the Ordinance of the Minister of the Environment of 14 August 2009 on the report for the creation of the National Register of Discharges and Transfer of Wastes (No 141, item 1515), which specifies the specimen form for the report to be made National Pollutant Release and Transfer Register, form and required techniques for submitting such report [33]. PRTR collects data on pesticides, heavy metals, non-organic substances, organic chlorinated substances and other information including priority substances. The register contains data on releases of these pollutants into water, soil, air, their off-site transfers, pollutants in sewage, releases of pollutants from diffuse sources. This information can be searched in the database according to a number of criteria such as the type of pollutants, the geographical location of the industrial plant, the environmental elements to which the pollutant is released, according to the plant owner or the type of industry [34].

Types of activities requiring PRTR reports are listed in Annex I of the Regulation and are [33,34]: energy industry (e.g. oil and gas refineries, electro-flare plants), metal production and processing (e.g. ore roasting and sintering installations chemical industry (e.g. chemical installations for the production of basic organic and inorganic compounds, fertilizers, biocides, plant protection products), waste management and waste management, waste water (e.g. waste water treatment plants, waste landfills), paper and wood production and processing, intensive poultry or pig farming, other activities such as tanneries or dairies. An operator of at least one establishment engaged in the activities listed in Annex I to this Regulation is obliged to report annually to the competent national authority on the quantitative releases of pollutants in Annex II of that Regulation (including all priority substances) to air, water and offsite transfers. These data can be based on measurement, calculation or estimation and are reported in unit $\mathrm{kg} / \mathrm{year}$ and waste in unit $\mathrm{Mg} /$ year. Member States shall set a deadline by which all facility operators communicate the data to the authorities. The data is then transmitted electronically to the European Commission [34].

\section{Conclusions}

Priority substances that occur in surface or underground water can be natural and anthropogenic origin and belong to many different groups of substances such as hydrocarbons, heavy metals, organometallic compounds, chloroorganic compounds, polycyclic aromatic hydrocarbons and others. A large proportion of all priority substances are pesticides. The vast majority of priority substances exhibit toxicity to living organisms. The Water Framework requires the presence of contaminants in the waters to be monitored. Data collected during the monitoring of waters are used, among others, to classify the state of surface water bodies or to create rankings of priority substances. Ultimately, the aim is to bring the environment to a state in which the concentration of priority substances will not exceed the intrinsic background concentration of the aquatic ecosystem.

Determining the presence in surface waters of priority substances and identifying sources of water pollution allows action to be taken to improve water quality. Good water status can be achieved mainly by eliminating and reducing discharges of these substances by industrial plants or waste water treatment plants.

\section{References}

1. Directive $2000 / 60 /$ EC of the European Parliament and of the Council of 23 October 2000 establishing a framework for Community action in the field of water policy.

2. Ordinance of the Minister of the Environment of 6 May 2016 on the list of priority substances, Journal of Laws from 2016 item 681.

3. Dichlorvos. EXTOXNET 1996. http://extoxnet.orst.edu/pips/dichlorv.htm, data of access: 15.04.2017.

4. Diuron. Chemical Fact Sheet. http://www.speclab.com/compund, Spectrum Laboratories, Inc., data of access: 17.04.2017.

5. A. Bressy, M.C. Gromaire, C. Lorgeoux, M. Saad, F. Leroy, G. Chebbo, Water Res. 46 (2012)

6. R. Pitt, R. Field, M. Lalor, M. Brown, Water Environ. Res. 67 (1995)

7. S. Zgheib, R. Moilleron, M. Saad, G. Chebbo, Water Res. 46 (2012)

8. N. Marti, D. Aguado, L. Segovia-Martinez, A. Bouzas, A. Seco Mar. Pollut. Bull. 62 (2011)

9. J. Robles-Molina, B. Gilbert-Lopez, J.F. Garcia Reyes, A. Molina-Diaz, Talanta. 82 (2010)

10. L. Patrolecco, N. Ademollo, S. Capri, R. Pagnotta, S. Polesello, Chemosphere 81, 11, (2010)

11. M. Gono, M. Kyncl, R. Gono, I. Kłosok-Bazan, P E 11, 89 (2013)

12. I. Zimoch, B. Kotlarczyk, A. Sołtysik Ochr. Sr. 29, 3 (2007) 
http://www.os.not.pl/docs/czasopismo/2007/Zimoch 3-2007.pdf

13. J. Boguniewicz-Zablocka, I. Klosok-Bazan, V.Naddeo, Environ Sci Pollut Res (2017). https://doi.org/10.1007/s11356-017-0608-8

14. G. Svecevicius, Acute Toxicity of Nickel to Five Species of Freshwater Fish (Institute of Ecology of Vilnius University. Vilnius, 2009)

15. A. Tuvikene, Responses of fish to polycyclic aromatic hydrocarbons (PAHs) (Finnish Zoological and Botanical Publishing Board. Helsinki, 1995)

16. Environmental health criteria. Lead - environmental aspects. World Health Organization. Geneva, 1989

17. European Union Risk Assessment Report. Alkanes, C10-13, chloro. Institute for Health and Consumer Protection Office for Official Publications of the European Communities. Italy, 2000.

18. R. Eisler, Polycyclic Aromatic Hydrocarbon Hazards to Fish, wildlife and Invertebrates: Synoptic Review. U.S. Fish and Wildlife Service, 1987.

19. J.F. Risher, Elemnetal Merkury and inorganic Merkury compounds: human health aspects, World Health Organization, 2003.

20. Environmental Quality Standards (EQS) Substance Data Sheet. Common Implementation Strategy for the Water Framework Directive. Brussels, 2005.

21. European Union Risk Assessment Report. Alkanes, C10-13, chloro. Institute for Health and Consumer Protection Office for Official Publications of the European Communities. Italy, 2000.

22. I .Zimoch, E. Łobos, Desalin. and Water Treat. 52, (2014) https://doi.org/10.1080/19443994.2014.884684

23. I. Zimoch, Ochr. Sr. 29, 4 (2007) http://www.os.not.pl/docs/czasopismo/2007/Zimoch 4-2007.pdf

24. M. Bożym, I. Kłosok-Bazan, M. Wzorek, Pol. J. Environ. Stud. 27, 3 (2018) DOI: $10.15244 /$ pjoes $/ 75828$

25. Cadmium In Drinking-water. Background document for development of WHO Guidelines for Drinkingwater Quality, World Health Organization, 2011.

26. Toxicological profile for cadmium. Agency for Toxic Substances and Disease Registry (ATSDR), 2012.

27. Agency for Toxic Substances and Disease Registry, Toxicological profil for lead, U.S. Dprt. of Health and Human Services, 2007.

28. Environmental Handbook Volume III: Compendium of Environmental Standards (GTZ; 1995)

29. Act of 18 July 2001 Water Law, Journal of Laws from 2001 No. 115 item 1229.

30. Dangerous substances for the Baltic Sea environment - properties, sources and reduction of emissions. COHIBA. Institute of Ecology of Industrial Areas. 2012.
31. Regulation (EC) No 1907/2006 of the European Parliament and of the Council of 18 December 2006 (REACH).

32. Directive 2010/75/EU of the European Parliament and of the Council of 24 November 2010 on industrial emissions (Integrated Pollution Prevention and Control).

33. F. Oosterhuis, Substitution of hazardous chemicals. Institute for Environmental Studies (IVM). Vrije Universiteit. Amsterdam, 2006.

34.http://www.katowice.pios.gov.pl/monitoring/pms/wo dy.pdf, data of access: 08.04.2017. 